\title{
TINDAK TUTUR \\ DALAM UPACARA ETNIS TIONGHOA PERANAKAN
}

\author{
THE SPEECH ACTS \\ IN CHINESE INDONESIAN ETHNIC WEDDING
}

\author{
Marissa Leviani Sugiarto $^{1^{*}}$, Deli Nirmala ${ }^{2}$ \\ Magister Linguistik, Universitas Diponegoro, Indonesia ${ }^{1,2}$ \\ marissa.levianis@gmail.com ${ }^{1}$, deli.nirmala@gmail.com ${ }^{2}$ \\ *penulis korespondensi
}

\begin{tabular}{l}
\hline Info Artikel \\
\hline Sejarah artikel: \\
Diterima: \\
2 Desember 2019 \\
Direvisi: \\
27 Desember 2019 \\
Disetujui: \\
14 Januari 2020 \\
\\
Kata kunci: \\
Penutur, tuturan, \\
pernikahan,tindak tutur \\
ilokusi
\end{tabular}

\begin{abstract}
ABSTRAK
Penelitian ini membahas tindak tutur Pandita dan kedua mempelai dalam pernikahan etnis Tionghoa Peranakan di Klenteng Kebon Jeruk, Semarang. Dalam pengumpulan data, peneliti melakukan perekaman dan observasi partisipan dalam pernikahan di Klenteng Kebon Jeruk, Semarang. Dari analisis ditemukan bahwa semua tindak tutur ada dalam peristiwa komunikasi pernikahan ini. Walau Pandita dan kedua mempelai memiliki kapasitas berbicara yang sangat berbeda. Urutan tindak tutur partisipan utama yang terbanyak yaitu Pandita, mempelai pria, dan mempelai wanita. Pandita berperan dominan dilihat dari kuantitas tindak tutur. Peran Pandita dalam upacara sebagai pengendali terlihat jelas dari jumlah tindak tutur direktif yang muncul. Makna dari tindak tutur tersebut menginstruksi kedua mempelai untuk mengikuti apa yang dikatakan Pandita. Mempelai pria dan wanita memiliki porsi bicara yang sama dan terbatasi terlihat dari jumlah tindak tutur mereka. Upacara pernikahan etnis Tionghoa peranakan mengakomodasi Pandita untuk mengambil kendali penuh atas pernikahan etnis tersebut dan sekaligus mengontrol tindak tutur mempelai. Kedua mempelai menggunakan tindak tutur komisif berjanji untuk hidup dengan rukun dan menaati ajaran Budha dalam pernikahan dan asertif yang memaknai respons tindak tutur direktif Pandita.
\end{abstract}

\begin{tabular}{|c|c|}
\hline Article Info & ABSTRACT \\
\hline $\begin{array}{l}\text { Article history: } \\
\text { Received: } \\
\text { 2 December } 2019 \\
\text { Revised: } \\
\text { 27 December } 2019 \\
\text { Accepted: } \\
\text { 14 January } 2020 \\
\text { Keywords: } \\
\text { speaker, utterance, } \\
\text { marriage, speech act, } \\
\text { illocution }\end{array}$ & $\begin{array}{l}\text { This study discusses the speech acts of a priest and the bride and groom in } \\
\text { a Chinese ethnic marriage at Kebon Jeruk Temple, Semarang. In collecting } \\
\text { data, researchers conducted the recording and observation of participants in } \\
\text { marriage at the Kebon Jeruk Temple, Semarang. From the analysis, the } \\
\text { researchers find that all speech acts existed in this marriage communication } \\
\text { event, although the priest and the bride and groom have a very different } \\
\text { speaking capacity. The main sequence of speech acts of the main } \\
\text { participants was the priest, bridegroom, and bride. Priest plays a dominant } \\
\text { role in terms of the number of speech acts. The role of the priest in the } \\
\text { ceremony as a controller is evident from the number of directive speech acts } \\
\text { that arise. The bride and groom have the same portion of speech and are } \\
\text { limited in their number of speech acts. The Chinese descents' wedding } \\
\text { ceremony accommodates the priest to take full control of the ethnic marriage } \\
\text { and at the same time, control the speech acts of the bride and groom. The } \\
\text { bride and groom use commissive and assertive speech acts, which are } \\
\text { responses to the priest's directive speech acts. }\end{array}$ \\
\hline
\end{tabular}




\section{PENDAHULUAN}

Indonesia yang terdiri dari beragam suku bangsa yang mempunyai bahasa daerah, adat istiadat, dan tata cara yang berbeda. Keberagaman budaya tersebut tidak hanya meliputi kesenian atau pun kerajinan yang khas. Akan tetapi, hal tersebut juga terlihat dalam peristiwa hidup manusia dari lahir. Proses hidup manusia dari berbagai etnis atau suku tersebut mengandung arti dari setiap makna kehidupan manusia dalam suatu etnis termasuk di dalamnya adalah pernikahan.

Etnis yang menjadi fokus dalam penelitian ini adalah etnis Tionghoa peranakan yang merupakan etnis Tionghoa yang lahir di Indonesia. Etnis ini menambah keragaman budaya di Indonesia. Akan tetapi, kajian linguistik mengenai etnis Tionghoa peranakan masih minim.

Dalam pernikahan etnis Tionghoa peranakan di Klenteng Kebon Jeruk ini dilaksanakan untuk mengupas tindak tutur dan peran masing-masing penutur utama dalam pernikahan yang dibalut nilai-nilai leluhur agama Budha dan etnis Tionghoa peranakan.

Dalam peristiwa komunikasi, penutur memiliki maksud atau tendensi lain di balik tuturan. Tidak hanya sekedar menghasilkan ujaran berupa struktur kata ataupun kalimat, tetapi penutur tersebut sebenarnya melakukan tindakan-tindakan melalui ujaranujaran yang diucapkan. Menurut Yule (1996: 47), tindakan-tindakan yang dilakukan melalui ujaran disebut sebagai tindak tutur.

Austin (1955: 94-107) membagi tindak tutur menjadi tiga jenis yaitu tindak lokusi, tindak ilokusi, dan tindak perlokusi. Tindak lokusi merupakan tindak mengujarkan sebuah ekspresi linguistik yang bermakna. Tindak ilokusi merupakan tindak ujaran yang mengandung daya fungsi komunikatif untuk mencapai berbagai tujuan komunikasi seperti membuat pernyataan, membuat janji, melakukan penawaran dan lain-lain. Tindak perlokusi merupakan efek atau tindakan pendengar yang diakibatkan dari ujaran yang dihasilkan. Dari ketiga bagian tindak tutur tersebut penelitian ini berfokus pada tindak ilokusi.

Vandervaken (1990:14-15) mengklasifikasi bentuk sintaksis kalimat dalam mengungkapkan tindak ilokusi yang terdiri dari:

a. Kalimat deklaratif adalah kalimat yang digunakan untuk menyatakan sesuatu.

b. Kalimat pengandaian adalah kalimat yang digunakan untuk menyatakan bagaimana sesuatu akan terjadi jika sebuah fakta terjadi di masa yang akan datang.

c. Kalimat imperatif adalah kalimat yang digunakan untuk meminta pendengar melakukan sesuatu.

d. Kalimat introgatif adalah kalimat yang digunakan untuk menanyakan sesuatu.

e. Kalimat eksklamatif adalah kalimat yang digunakan untuk mengungkapkan perasaan penuturnya.

f. Kalimat optatif adalah kalimat yang digunakan untuk menyatakan harapan penutur.

g. Kalimat subjungtif adalah kalimat yang digunakan untuk menyatakan keinginan penuturnya.

Bentuk kalimat dalam tindak ilokusi berhubungan dengan fungsinya. Searle (1979: 354-361) mengelompokkan lima klasifikasi fungsi tindak ilokusi yaitu sebagai berikut. 
a. Asertif adalah tindak tutur yang mengikat penuturnya akan kebenaran atas apa yang diujarkan. Kata kerja yang termasuk dalam klasifikasi asertif antara lain: menyatakan, mengakui, melaporkan, menunjukkan, menyebutkan, dan menjelaskan.

b. Direktif adalah tindak tutur yang digunakan untuk meminta pendengar melakukan sesuatu. Kata kerja yang termasuk dalam klasifikasi direktif antara lain meminta, menyuruh, memerintahkan, mengemis, memohon, berdoa, mengundang, mengajak, menyarankan, melarang dan memperingatkan.

c. Komisif adalah tindak tutur yang digunakan untuk menyatakan maksud bahwa penutur berkomitmen untuk melakukan sesuatu di waktu yang akan datang. Kata kerja yang termasuk dalam klasifikasi komisif yaitu 'berjanji' dan 'bermaksud'.

d. Ekspresif adalah tindak tutur yang digunakan untuk menyatakan ekspresi psikologis atau perasaan penutur. Kata kerja yang termasuk dalam klasifikasi ekspresif antara lain berterima kasih, memberi selamat, memohon maaf, menyambut, menyesalkan dan berbelasungkawa.

e. Deklarasi adalah tindak tutur untuk menyatakan perubahan dunia melalui ujaran. Perubahan yang dimaksud antara lain perubahan status ataupun perubahan keadaan. Kata kerja yang termasuk dalam tindak tutur ini antara lain mengesahkan, memutuskan, membatalkan, melarang, mengizinkan, mengabulkan, mengangkat, dan mengampuni.
Menurut Yule (1996:49), maksud tindak ilokusi dalam tuturan dapat ditentukan melalui alat penentu daya ilokusi (Illocutionary Force Indicating Device/ IFID) yang terdiri dari verba performatif, susunan kata, tekanan dan intonasi tuturan. Dengan menggunakan alat penentu tersebut, penelitian ini akan menjabarkan mengenai tindak tutur yang dipakai oleh penutur utama yang terdiri dari Pandita, mempelai pria dan mempelai wanita. Setelah itu, penelitian ini melihat hubungan tindak tutur yang didapat dengan menggunakan IFID. Penelitian mengenai peristiwa komunikasi sebelumnya dilakukan oleh Kurniasih (2013) yang mengupas kajian etnografi dalam penatacaraan upacara pernikahan adat Jawa. Kurniasih berpendapat "upacara tersebut sebagai wahana pendidikan yang bertujuan memberikan bekal berupa ajaran dan nasihat kepada calon pengantin tentang nilai-nilai kehidupan rumah tangga yang ideal" (2013:2). Namun, pengaruh banyaknya tindak tutur peserta upacara beserta hubungan hal tersebut dengan peran penutur belum dikupas dengan teori tindak tutur yang bisa mengupas strategi komunikasi penutur sehingga mitra tutur setidaknya mendengarkan tuturan penutur.

Selain Kurniasih, Yustiani (2016) meneliti komponen komunikasi beserta hubungan antar komunikasi dan tindak tutur pembicara seminar bisnis tersebut. Akan tetapi, Yustiana (2016) meneliti tentang peristiwa komunikasi dalam presentasi bisnis MLM (Multi Level Marketing). Yustiana tidak berfokus terhadap penelitian tindak tutur, tetapi komponen tutur serta hubungan komponen tutur tersebut satu sama lain. Yustiana (2016) hanya 
menyebutkan klasifikasi tindak tutur tanpa interpretasi lebih lanjut akan peran tindak tutur tersebut dalam peristiwa komunikasi presentasi tersebut. Padahal pembahasan klasifikasi tindak tutur dengan menyediakan jumlah setiap tindak tutur dapat mengungkap kecenderungan penutur dalam mencapai tujuan sebuah peristiwa komunikasi.

Maka dari itu, penelitian mengenai tindak tutur upacara pernikahan etnis Tionghoa peranakan ini dilakukan dengan mengaitkan hasil secara detail dengan peranan masingmasing penutur.

\section{METODE}

Penelitian tindak tutur upacara pernikahan etnis Tionghoa di Klenteng Kebon Jeruk, Semarang ini merupakan penelitian kualitatif. Menurut Djajasudarma (2006:9), metode yang membuat gambaran secara jelas, sistematik, dan saksama dalam objek yang diteliti dikategorisasikan sebagai metode penelitian deskriptif. Peneliti tidak mencari generalisasi dari data yang diamati dengan populasi yang lebih luas lagi, tetapi mencoba untuk mencari spesifikasi dari data verbal dan nonverbal pada pernikahan etnis Tionghoa di Klenteng Kebon Jeruk, Semarang.

Spradley (1997) kemudian mengatakan bahwa etnografi tidak hanya mempelajari masyarakat, tetapi juga belajar dari masyarakat itu sendiri. Spradley mengungkapkan bahwa makna-makna yang bisa diamati oleh peneliti etnografi terbagi ke dalam dua wilayah yakni makna yang terekspresikan dan yang disembunyikan. Makna yang terekspresikan secara langsung dapat diamati lewat bahasa lisan yang eksplisit, sedangkan yang tersembunyi bisa diamati melalui maksud implisit dari perkataan seseorang dan juga melalui perilaku dari sumber yang diamati.

Untuk mendapatkan data, peneliti mencari informasi terlebih dahulu mengenai klenteng di Semarang. Peneliti memutuskan Klenteng Kebon Jeruk karena merupakan Klenteng yang sudah lama berdiri di Semarang. Untuk melakukan perekaman, peneliti menghubungi pengurus Klenteng Kebon Jeruk mengenai tanggal upacara pernikahan yang akan berlangsung. Saat itu yang terdekat adalah 1 Mei 2015. Oleh karena itu, peneliti meminta izin untuk melakukan perekaman, observasi sepanjang upacara kurang lebih 1,5 jam dan wawancara setelah upacara selesai. Peneliti menggunakan metode simak, teknik sadap, dan teknik simak bebas libat cakap serta teknik catat dalam penelitian ini.

Observasi dilakukan dengan berpartisipasi sebagai pengamat dan melakukan pencatatan dan perekaman secara langsung ketika upacara pernikahan etnis pada tanggal 1 Mei 2015. Peneliti mencari informasi mengenai tanggal pernikahan di Klenteng Kebon Jeruk, Semarang. Setelah mengetahui tanggal pernikahan dan peneliti meminta izin terlebih dahulu untuk merekam acara pernikahan di tempat tersebut dari awal hingga selesai acara.

Selanjutnya, rekaman tersebut ditranskripsi dan diklasifikasi dengan teori tindak klasifikasi tindak tutur (Searle, 1979) dengan metode padan untuk menemukan fungsi tuturan tersirat atau yang tidak bisa diklasifikan dengan mencari struktur kalimat semata. Teori tindak ilokusi berdasarkan bentuk sintaksis kalimat (Vandervaken, 1990). Kemudian hasil analisis data disajikan dengan 
mendeskripsikan bentuk dan fungsi tuturan serta komponen komunikasi dalam penataan cara upacara pernikahan adat Tionghoa.

\section{HASIL DAN PEMBAHASAN}

Bentuk dan Fungsi Tuturan dalam Upacara Pernikahan Etnis Tionghoa

Tuturan-tuturan yang diteliti dalam upacara pernikahan etnis Tionghoa peranakan diujarkan oleh Pandita (P) serta mempelai pria (MP) dan mempelai wanita (MW). Tuturantuturan dalam upacara pernikahan etnis Tionghoa diklasifikasikan berdasarkan klasifikasi fungsi tindak tutur lalu setiap data dianalisis berdasarkan bentuk kalimat dan bukti linguistik yang merupakan penanda daya ilokusi fungsi tuturan. Dalam pengklasifikasian, maksud tindak ilokusi dalam tuturan dapat ditentukan melalui alat penentu daya ilokusi (Illocutionary Force Indicating Devicel IFID) yang terdiri dari verba performatif, susunan kata, tekanan dan intonasi tuturan.

Secara keseluruhan, tindak tutur direktif digunakan paling banyak. Hal ini menunjukkan dominasi tindak tutur dalam upacara pernikahan etnik Tionghoa peranakan yang didominasi oleh banyak instruksi dan peragaan. Makna pragmatis dari tindak tutur direktif yang ditemukan dalam data adalah meminta, menyuruh, memerintahkan, memohon, berdoa, mengundang, mengajak, menyarankan, melarang, dan memperingatkan.

Urutan selanjutnya adalah tindak tutur asertif yang meliputi makna menyatakan, mengakui, menunjukkan, menyebutkan, dan menjelaskan.

Yang ketiga, tindak tutur komisif yang mempunyai makna berjanji. Selanjutnya, tindak tutur ekspresif yang bermakna berterima kasih dan menyesalkan. Yang terakhir, tindak tutur deklaratif yang mempunyai makna mengesahkan hubungan antara kedua mempelai.

Tabel 1. Jumlah Total Bentuk Tindak Tutur dalam Upacara Pernikahan di Klenteng Kebon Jeruk, Semarang

\begin{tabular}{|c|c|}
\hline Jenis tuturan & Jumlah tururan \\
\hline Direktif & 87 tuturan \\
\hline Asertif & 46 tuturan \\
\hline Komisif & 6 tuturan \\
\hline Ekspresif & 2 tuturan \\
\hline Deklaratif & 1 tuturan \\
\hline Jumlah & $\mathbf{1 4 2}$ tuturan \\
\hline
\end{tabular}

\section{Tindak Tutur Direktif}

Tindak tutur ini mendominasi tuturan secara keseluruhan dan terkandung dalam tuturan-tuturan yang diujarkan oleh Pandita. Tuturan direktif ini terdiri dari beberapa fungsi memberi instruksi, melarang, memperingatkan, memberi aba-aba, mengajak, menasehati, menyarankan dan mempersilahkan. Tuturan tersebut diujarkan dengan beberapa bentuk kalimat yaitu imperatif, interogatif, dan deklaratif.

Tindak tutur yang berfungsi untuk menunjukkan keberadaan simbol terdapat pada peragaan kain bunga merah. Tindak tutur ini diujarkan oleh $\mathrm{P}$ sebelum mereka memberikan instruksi pada mempelai untuk melakukan peragaan. Intonasi dalam berbicara Pandita tidaklah datar, sehingga orang yang mendengar akan tahu kalau intonasinya cukup jelas menginstruksikan. Walaupun tidak menggunakan kata-kata "saya menginstruksikanmu untuk bertukar tempat", tetapi pendengar akan tahu secara langsung akan instruksi tersebut. P: "Iya, tukar." 
Pada saat itu Pandita memberi intruksi agar MP bertukar posisi dengan MW dengan tangan menunjuk ke tempat MP, lalu pindah ke sebelah kiri MW dengan menghadap ke meja persembahan. Bentuk tuturan tersebut berupa kalimat imperatif dengan verba 'tukar' dengan maksud meminta mempelai untuk melakukan suatu tindakan yaitu bertukar tempat. Hal tersebut dikategorisasikan sebagai tindak ilokusi direktif.

Tindak tutur yang berfungsi memberi instruksi yang diberikan bervariasi tergantung dari tata cara yang dilakukan. Berikut adalah contoh tuturan-tuturan memberi instruksi yang diambil dari tata cara sembahyang pernikahan Tionghoa agama Budha yang disampaikan oleh Pandita.

Intonasi Pandita ketika berucap tidak datar, sehingga orang yang mendengar akan tahu kalau intonasinya cukup jelas menginstruksikan. Walaupun tidak menggunakan katakata 'saya memintamu untuk berdoa dan berlutut', tetapi pendengar akan tahu secara langsung akan instruksi tersebut.

P: Baik, setelah berdoa, pai, berlutut.

Pandita memberikan instruksi agar kedua mempelai berdoa, berlutut dan pai. Ketiga kata tersebut adalah verba aktif berdoa, berlutut, dan berdiri. Pandita menginstruksi MP dan MW untuk berdoa dan selanjutnya pai di hadapan patung Budha lalu berlutut. Verba pai berasal dari Bahasa Mandarin yang berarti memberi hormat dengan cara mengepalkan kedua jari tangan.

Tindak tutur direktif meminta selanjutnya adalah ketika Pandita memberi intruksi agar mempelai mengucapkan terima kasih pada Tuhan. Tuturan Pandita tersebut secara sintaksis merupakan kalimat imperatif. Selain itu, verba berkata yang merupakan kata awal yang diucapkan adalah ciri dari tindak tutur direktif.

Struktur kalimat dari tuturan di bawah diawali oleh verba yang merupakan ciri dari kalimat imperatif. Intonasi dalam berbicara Pandita memiliki penekanan, sehingga orang yang mendengar akan tahu kalau intonasinya cukup jelas menginstruksikan. Walaupun tidak menggunakan kata-kata 'saya menginstruksikanmu untuk mengucap terimakasih', tetapi pendengar akan langsung tahu akan instruksi tersebut.

\section{P: Ucapkan terima kasih, Tuhan.}

Tuturan ucapan terimakasih tersebut diujarkan, ketika kedua mempelai telah selesai menghormati orang tua dan mertua masing-masing.

Tuturan selanjutnya terjadi ketika Pandita menghendaki kedua mempelai untuk memberi hormat kepada mertua masing-masing mempelai. Pandita memiliki keterbatasan dalam penggunaan Bahasa Indonesia baik dan benar. Akan tetapi, tuturannya yang singkat masih bisa dimengerti. Tuturan lengkap yang dimaksud Pandita "coba bisa (jalan) ke arah mertua." Syntax dari tuturan Pandita ini merupakan struktur kalimat imperatif yang diawali dengan verba aktif 'coba'.

\section{P: Coba bisa ke arah mertua, arah mertua.}

Verba tersebut adalah kata yang fungsinya menginstruksi dengan cara halus. Tuturan di atas merupakan instruksi dan bukan merupakan saran 
karena intonasi dan nada penutur lebih tegas daripada sekedar mengajak.

Tuturan pandita selanjutnya adalah setelah MP membungkuk tiga kali kepada patung Budha yang ada di hadapannya sambil berdiri. $P$ menggunakan kata kerja pasif yaitu di taruhkan. Verba pasif tersebut merujuk pada benda yang harus diletakkan MP. Tuturan lengkap yang ingin dimaksudkan pandita adalah "(dupa diharapkan) ditaruhkan ke atas tempat dupa". Ditilik secara susunan sintaksis, kalimat dibawah ini merupakan kalimat pasif. Intonasi dalam penyampaian tuturan ini agak datar dan menyuruh.

\section{P: Ditaruhkan ke atas tempat dupa. Memberi hormat tiga kali ini juga.}

Pandita menginstruksi MP untuk menancapkan hio ke tempat dupa. Verba memberi merupakan kata kerja aktif. Tuturan yang diucapkan Pandita merupakan bentuk kalimat yang tidak lengkap dari tuturan "mempelai memberi hormat tiga kali...". Tuturan tersebut berbentuk kalimat deklaratif.

Selain contoh data di atas, tuturan yang ducapkan oleh Pandita di bawah ini merupakan tindak tutur direktif yang berfungsi menginstruksi MP untuk memposisikan diri ke arah yang ditunjukkan pandita. Pada saat itu, Pandita akan memulai prosesi pemberkatan.

\section{P: Yang laki sebelah sana.}

Tuturan lengkap dari dari tuturan di atas adalah "yang laki (pindah) ke sebelah sana". Struktur kalimat di atas tidak memiliki verba sama sekali, akan tetapi maksud dari Pandita adalah meminta mempelai pria untuk pindah tempat. Tindak tutur direktif di atas ini dinyatakan dalam bentuk deklaratif yang fungsinya yaitu menginstruksi. Walaupun tidak menggunakan verba di awal tuturan, tetapi tuturan tersebut diklasifikan sebagai tindak tutur direktif karena menunjukkan arah MP harus pergi.

Tindak tutur ini berfungsi menginstruksikan atau menasehati mempelai untuk tidak melakukan sesuatu hal. Dalam upacara pernikahan, Panditalah yang memang memiliki porsi paling besar dalam tuturan direktif di bawah. Pola kalimat tuturan di bawah tersebut merupakan kalimat imperatif yang diawali dengan kata 'jangan' diikuti verba aktif duduk.

Hal tersebut menegasikan verba performatif duduk sehingga tindak perlokusi yang dilakukan oleh mempelai adalah bangkit dari kursinya. Jangan adalah kata yang digunakan oleh penutur untuk melarang. IFID intonasi di tuturan ini berperan dalam keberhasilan tindak perlokusi. Pada saat itu, kedua mempelai seharusnya melakukan pai ciu, akan tetapi kedua mempelai tidak paham dan malah duduk di kursi.

P: Jangan duduk dulu, pai ciu 3 kali.

Setelah larangan duduk, Pandita selanjutnya menggunakan verba performatif pai ciu atau yang artinya berlutut untuk mendorong pendengar melakukan tindak perlokusi yang Pandita agar diikuti oleh mempelai. Verba tersebut Selain hal itu, intonasi yang dipakai seperti menentang dalam keadaan terdesak.

P: Hop. [berhenti]

Kata hop berarti 'berhenti'. Pandita saat itu melarang agar jangan meletakkan kertas doa terlalu dekat dengan api. Kertas merah dibakar diujung, lalu 
diletakkan di sela hio yang menancap di tempat hio. Peletakannya harus tepat karena diyakini bahwa kertas itu harus terbakar habis sehingga doa bisa terkabul.

Verba performatif 'berhenti' adalah bukti fisik IFID yang menentukan tuturan ini diklasifikasi sebagai tindak tutur direktif. Selain itu, intonasi dan penekanan kata Pandita juga berperan dalam penentuan tindak tutur ini.

Tindak tutur direktif yang berfungsi mengingatkan mempelai diucapkan oleh Pandita setelah upacara pemberkatan selesai. Sesudah pemberkatan di Klenteng, mempelai diberikan kebebasan untuk memberikan tanda kasih kepada pihak Klenteng.

$$
\begin{aligned}
& \text { P: Nanti jangan lupa kasih } \\
& \text { persembahan kasih. }
\end{aligned}
$$

IFID yang berperan dalam tuturan di atas adalah intonasi. Jangan merupakan kata yang berfungsi melarang, tapi dalam situasi ini Pandita bermaksud untuk mengingatkan agar jangan lupa memberikan uang persembahan.

Tindak tutur direktif yang berfungsi mengingatkan selanjutnya diucapkan oleh pandita. Pandita mengesahkan acara dengan mengingatkan kembali kedua mempelai untuk menandatangani surat nikah setelah menandatangani dokumen lain sebelumnya. Tuturan di bawah ini secara susunan kata tidak diawali oleh verba aktif menandatangani. Namun, maksud dari Pandita yang sebenarnya adalah tanda tangani. Intonasi dan penekanan dalam tuturan di bawah membantu kedua mempelai mengerti tindak perlokusi apa yang harus dilakukan.
P: Menandatangani kertas lagi.

Ketika tuturan tersebut mempunyai intonasi datar dan tanpa penekanan, maka kedua mempelai akan mengira tuturan tersebut sebagai kalimat deklaratif. Secara tujuan, tuturan tersebut diklasifikasikan sebagai tindak tutur direktif karena penutur membuat pendengar melakukan apa yang dikatakan.

Tindak tutur yang berfungsi mengajak hanya terdapat pada peragaaan simbol. Dalam peragaan simbol tersebut $\mathrm{P}$ mengajak MP dan MW setelah menghadap ke mertua untuk melakukan ritual lain. Berikut adalah data tuturannya.

P: Yuk, iyak sudah. Makasih.

Data tuturan di atas berbentuk kalimat deklaratif untuk mengajak mempelai. Pada data tuturan di atas, tuturan ajakan berterima kasih diungkapkan oleh $\mathrm{P}$ ketika mempelai sudah memegang hio. Tuturan 'makasih' diucapkan Pandita agar kedua mempelai berlutut dan bersujud ke lantai dan mengucap terimakasih pada dewa dewi.

Tuturan selanjutnya merupakan ajakan untuk maju ke dekat altar. Pandita menggunakan pemarkah 'mari' untuk mempersilakan dan penggunaan IFID verba performatif 'maju' untuk menyampaikan maksud dalam tindak tutur direktif ini.

\section{P: Sudah selesai, mari maju.}

Intonasi dan penekanan dalam tuturan ini juga mendukung mempelai untuk mengerti maksud Pandita.

\section{Tindak Tutur Asertif}

Dalam upacara pernikahan etnis Tionghoa, tuturan yang diklasifikasikan sebagai tindak tutur 
asertif, dinyatakan baik oleh $\mathrm{P}$ dan juga oleh MP dan MW.

Tindak tutur asertif tersebut berbentuk kalimat deklarasi yang menunjukkan fungsi yaitu menjelaskan mengenai peristiwa komunikasi yang sedang terjadi. Tuturan Pandita bersifat informatif. Pandita menggunakan verba kalimat aktif seperti 'menyetujui'. Intonasi yang digunakan Pandita datar dan penekanan pun tidak pada verba yang ada.

dì ȳ̄ shìpín héshàng shuō qínglü fèngxiàn qìngzhù huódòng de yìyàn bìxià yēhéhuá făngfú de mingchēng jīngjì rén yīng de míngchēng yìndùnixxìyà zhōngyāng zhăowā dìming chóngbài méntú zhè qinglǘ yuànyì jiāng zhàngfū hé qīzi yŏu tóngyì de fùmǔ shuāngfāng băo tā de jīchŭ shàng dá guānyīn púsà yuè yuè yīnwèi yēhéhuá shàngdì tǒngzhì hé yēhéhuá shàngdì tǒngzhì zài chá zài wǔ zhǒng shuĭguǒ hé gè qídăo de héping yŭ shēntǐ jiànkāng [Pasangan akan diabadikan, merayakan keinginan untuk berkat Tuhan di Klenteng Low Lie Bio, Jawa Tengah, Indonesia. Mengadakan penghormatan dari murid Edy Pramono dan Herlina Sunarto pasangan baru ini, yang ingin menikah, memiliki kedua belah pihak orang tua setuju. Hargailah itu Klenteng Low Lie Bio Guanyin Bodhisattva. Jadikanlah sebagai contoh. Dirikan altar Kwan Im beserta aroma teh yang wangi, lima buah dan enam sayur-sayuran, berdoa untuk kedamaian. Tolong Tuhan, Tuhan, P terima kasih, 1 Mei 2015.]

Tuturan di atas terdiri dari banyak informasi mengenai peristiwa komunikasi yang terjadi dan peran dari masing-masing pihak.
Data tuturan selanjutnya dapat dilihat di bawah ini. Tindak tutur yang berfungsi untuk menjelaskan makna dan harapan adalah tuturan berikut. Tindak tutur ini diujarkan oleh P ketika mempelai sudah mulai ke daerah upacara.

P: Iyak. Semua harapan yang baik ketika nyuting ya.

Tuturan asertif di bawah ini diucapkan sebelum memulai upacara pernikahan, Pandita memberikan penjelasan kepada MP dan MW mengenai meja altar yang berisi barang-barang sembahyang. Nama altar tersebut adalah Bun Sen.

P: Ini altar Bun Sen.

Pandita menjelaskan nama altar tersebut dengan menggunakan kalimat deklaratif. Kata demonstratif 'ini' menunjuk kepada benda yang dimaksud Pandita.

Tindak tutur asertif lain yaitu Pandita memimpin MP dan MW untuk memberikan hormat kepada dewa yang ada di Klenteng Kebon Jeruk tersebut.

P: Pai Kun Sen (adalah) malaikat kuil ini.

Pandita menjelaskan bahwa malaikat yang ada di kuil atau klenteng tersebut adalah Pai Kun Sen. Tututan di atas merupakan tuturan lisan, sehingga kata 'adalah' tidak dipakai dalam tuturan di atas.

Tindak ilokusi tuturan di atas jelas. Menginformasikan mengenai altar Pai Kun Sen menjadi tujuan dari tuturan di atas. IFID dari tuturan di atas tidak berupa bukti yang fisik. 


\section{Tindak Tutur Komisif}

Tindak tutur komisif mengandung maksud bahwa penutur akan melakukan sesuatu hal sesuai yang penutur ucapkan. Dalam upacara ini, tindak tutur komisif ini hanya diujarkan oleh MP dan MW pada upacara ikrar janji suci. Berikut adalah data tuturannya.

MP: Saya Edy Pramono akan berjanji akan menjaga dengan sepenuhnya akan menjadi suami yang bertanggung jawab yang rukun damai bahagia penuh kasih sayang akan menjaga dia. Akan menganut ajaran Tridharma dalam rumah tangga. Akan selalu menjaga keutuhan umat. Saya tridarma dengan tri guna hari ini akan berjanji, saya Edy Pramono akan berjanji akan melihat Edy Pramono sebagai pembimbing rohani akan menjaga dia sebaikbaiknya, akan menjadi suami yang bertanggung jawab bersedia menerima dalam kesusahan maupun kesenangan menjaga rumah tangga yang rukun dengan dia bahagia berdasarkan cinta yang suci luhur. Akan setia pada ajaran agama tridharma dalam mencinta dan membina keluarga. Dalam membina hubungan akan menaati ajaran tridharma sama akan mengajarkan Tridarma bagi keluarga dan memimpin agama sehingga akan menjadi anak-anak yang keras dengan ajaran tridharma agar bisa menjadi orang yang berguna bagi dirinya dan negara. Akan selalu menjaga kerukunan rumah tangga sejauh ini dalam pernikahan.

Tuturan tersebut berbentuk kalimat komisif yang mengandung adverbia modalitas yaitu 'akan' dan verba aktif 'menjaga'. Adverbia modalitas 'akan' menunjukkan sesuatu yang akan dilakukan oleh penutur dan mitra tutur. Sedangkan verba aktif 'menjaga' menunjukkan kegiatan yang dilakukan oleh penutur.

Verba 'berjanji' di atas merupakan IFID dari tindak ilokusi komisif ini. Verba berjanji diucapkan karena mempelai pria ingin melakukan sesuatu untuk mempelai wanita pada waktu ke depan. Maka dari itu, tujuan dari tuturan tersebut adalah MP berniat untuk memberikan hak kepada MW untuk dijaga dengan tanggung jawab dan dikasihi oleh MP. Setelah pernyataan MP dan memberi hormat pada Tuhan dengan menghadap meja persembahan, acara upacara pemberkatan pernikahan bisa dilanjutkan dengan doa.

Tuturan selanjutnya merupakan tuturan dari MW yang menyatakan janji setia menjadi istri MP. MW menyatakan akan melakukan kewajiban yaitu mempunyai keturunan dan akan selalu menjaga hubungan bersama. Penutur juga menjanjikan sesuatu hal di kemudian hari mengenai apa yang akan dilakukan mempelai perempuan.

MW: Dalam waktu ini, saya Herlina Sunarto akan setia menjadi istri dalam hidupnya ikut andil dalam mendidik anak, ikut rumah dalam hidup yang terbaik menjadi pasangan yang setia, seiman jujur dalam segala yang baik damai dan dalam cinta yang suci. Akan lebih lama mencintai dalam duka dengan senang pada Tuhan, dan dengan giat mematuhinya. Segera mendapat keturunan yang banyak selalu menjadi istri dan anak dalam keadaan susah maupun senang serta selalu menjaga hubungan bersama dalam rumah tangga ini. 
Dalam tuturannya, MW juga menggunakan adverbia modalitas 'akan' dan adjektif 'setia', beberapa verba performatif yang dijanjikan seperti 'mendidik', 'menjadi', 'mencintai' sebagai IFID dari tuturan di bawah ini. Pengklasifikasian tuturan di atas sebagai tindak tutur komisif karena tuturan tersebut mengandung maksud MW untuk melakukan sesuatu di masa yang akan datang.

Tindak tutur komisif selanjutnya diucapkan oleh MW kepada ibu MW sendiri. IFID dalam tuturan di bawah ini bersifat implisit dikarenakan tidak adanya verba 'berjanji'. Akan tetapi, pendengar pasti akan tahu bahwa MW menjanjikan sesuatu karena ada suatu akhir pencapaian yang ingin diraih oleh MW.

MW: Mah Herlina nikah dulu buat rumah tangga rukun dan selamanya.

\section{Tindak Tutur Ekspresif}

Tindak tutur ekspresif mengungkapkan perasaan dan emosi penutur. Dalam upacara pernikahan etnis Tionghoa ini, tindak tutur ekspresif dinyatakan oleh pandita dalm tuturan di bawah ini. Pandita mengucapkan kata 'ha ya' yang merupakan interjeksi serapan Bahasa Mandarin. Interjeksi tersebut biasanya diucapkan oleh masyarakat keturunan Tionghoa. Kata tersebut biasanya diucapkan karena hal yang tidak diinginkan terjadi atau mengungkap perasaan jengkel.

\section{P: Ha ya. \\ [ya ampun]}

Ketika itu pandita mengeluh sambil menaruh kedua tangannya di pinggang karena pandita bingung mengapa kertas doa dibakar di depan meja persembahan. Seharusnya kertas doa dibakar di dekat tempat dupa. Intonasi pandita cukup tinggi dan terdengar jengkel. Penekanan suara berada di dua suku kata tersebut. ' $\mathrm{Ha}$ $y a$ ' merupakan kata interjeksi yang merupakan serapan Bahasa Mandarin.

\section{Tindak Tutur Deklaratif}

Dalam penelitian ini terdapat beberapa tuturan yang merupakan tindak tutur deklaratif. Di bawah ini merupakan salah satu contoh dalam bentuk kalimat deklaratif yang diucapkan oleh pandita dalam memberkati dan meresmikan hubungan kedua mempelai sebagai suami istri. Pandita juga menyebutkan jangka waktu pernikahan mereka berdua sampai Nibbana (kebebasan) tiba.

\section{P: Maka dengan ini, saya selaku Pendeta Lokapalasraya menyatakan bahwa mulai saat ini Saudara/Saudari berdua terikat sebagai suami istri yang sah dalam nama Buddha-Dharma- Sangha mulai dari sekarang hingga tercapainya Nibbana.}

Penutur merepresentasikan bahwa MP dan MW yang sebelum upacara pemberkatan merupakan lajang menjadi suami istri. Ucapan Pandita tersebut telah mengubah status MP dan MW. Pengklasifikasian data di atas sebagai tuturan deklaratif atas dasar pengubahan status kedua mempelai yang disebabkan setelah tuturan Pandita disampaikan.

Selain itu, susunan kata yang digunakan oleh Pandita merupakan susunan kalimat berita yang cenderung lengkap. Intonasi Pandita dalam berbicara cukup datar dan tidak ada penekanan khusus. Sejalan dengan 
tindak tutur deklaratif yang mempunyai fungsi menginformasikan dan bukan mengajak atau memperngaruhi.

\section{Hubungan Tindak Tutur dan Peranan Penutur dalam Upacara Pernikahan Etnis Tionghoa.}

Dalam Tabel 2 mengenai tindak tutur setiap penutur, Pandita paling banyak menggunakan tindak tutur direktif yang sangat mendominasi peristiwa upacara pernikahan tersebut. Peran Pandita di sini mengambarkan Pandita sebagai pengatur acara tersebut. Hal tersebut terlihat dalam banyaknya tindak tutur direktif yang diujarkan oleh Pandita. Peran mempelai pria dan wanita dalam pernikahan etnis ini bukan sebagai pengatur acara terlihat dari jumlah tindak tutur direktif yang nihil. Dalam pernikahan etnis Tionghoa peran Pandita di sini sangat signifikan sehingga peran kedua mempelai dalam upacara pernikahan mereka ini terbatas akan instruksi Pandita.

Tindak tutur asertif digunakan oleh semua penutur utama dengan urutan Pandita, mempelai pria, lalu mempelai wanita. Selain memberikan instruksi, Pandita juga memberikan penjelasan atas inisiatif sendiri kepada mempelai pria dan wanita beserta tamu yang hadir. Sedangkan, mempelai pria dan wanita menggunakan tindak tutur ini sebagai respons dari tindak tutur direktif Pandita.

Tabel 2. Jumlah Total Bentuk Tindak

Tutur Pandita dalam Upacara

Pernikahan di Klenteng Kebon Jeruk,

Semarang

\begin{tabular}{|c|c|c|c|}
\hline \multirow{2}{*}{$\begin{array}{c}\text { Jenis } \\
\text { tuturan }\end{array}$} & \multicolumn{3}{|c|}{ Penutur } \\
\cline { 2 - 4 } & Pandita & $\begin{array}{c}\text { Mempelai } \\
\text { Pria }\end{array}$ & $\begin{array}{c}\text { Mempelai } \\
\text { Wanita }\end{array}$ \\
\hline Direktif & 87 & 0 & 0 \\
\hline Asertif & 31 & 8 & 7 \\
\hline
\end{tabular}

\begin{tabular}{|c|c|c|c|}
\hline \multirow{2}{*}{$\begin{array}{c}\text { Jenis } \\
\text { tuturan }\end{array}$} & \multicolumn{3}{|c|}{ Penutur } \\
\cline { 2 - 4 } & Pandita & $\begin{array}{c}\text { Mempelai } \\
\text { Pria }\end{array}$ & $\begin{array}{c}\text { Mempelai } \\
\text { Wanita }\end{array}$ \\
\hline Komisif & 0 & 3 & 3 \\
\hline Ekspresif & 2 & 0 & 0 \\
\hline Deklarasi & 1 & 0 & 0 \\
\hline Jumlah & $\mathbf{1 2 1}$ & $\mathbf{1 1}$ & $\mathbf{1 0}$ \\
\hline
\end{tabular}

Selanjutnya, tindak tutur komisif hanya dipakai oleh kedua mempelai untuk menyatakan niat mereka untuk mengarungi bahtera rumah tangga bersama. Yang terakhir adalah tindak tutur ekspresif yang dituturkan oleh Pandita di sela menginstruksi kedua mempelai untuk melakukan peragaan. Tindak tutur ekspresif tersebut merupakan ungkapan kecewa spontan Pandita terhadap kedua mempelai yang belum memahami prosesi pernikahan.

\section{PENUTUP}

Dalam upacara pernikahan etnis Tionghoa peranakan, semua tindak tutur dalam teori Yule terklasifikasi dalam peristiwa tersebut. Namun setiap penutur mempunyai ciri yang berhubungan dengan peran mereka dalam peristiwa komunikasi pernikahan tersebut.

Beberapa hal lain yang dapat disimpulkan bahwa secara hierarkis dalam upacara ini, Pandita memiliki kedudukan tertinggi dan memiliki wewenang untuk mengatur berlangsungnya acara sehingga semua partisipan lainnya harus mengikuti apa yang disampaikan oleh Pandita. Hal tersebut terlihat dalam tindak tutur pandita paling banyak berupa tindak tutur direktif dengan makna menyuruh dan memerintah dengan tuturan langsung. Peran Pandita dalam peristiwa pernikahan etnis Tionghoa adalah sebagai pengatur peristiwa komunikasi utama. Pandita mempunyai peran penting dalam menjaga jalannya 
alur acara sehingga Pandita menggunakan tindak tutur langsung dalam upacara.

Kedua mempelai hanya menuturkan tindak tutur asertif sebagai tanggapan dari tindak tutur direktif yang dipakai oleh Pandita. Upacara pernikahan etnis Tionghoa peranakan memfasilitasi Pandita untuk mengendalikan penuh tindak tutur Pandita sendiri dan juga kedua mempelai. Mereka berdua memiliki porsi bicara yang sangat terbatas yaitu 2 klasifikasi tindak tutur yaitu tindak tutur asertif dan tindak tutur komisif dalam bentuk kalimat deklaratif yang berfungsi untuk berjanji.

Dalam penelitian ini, Pandita menuturkan tindak tutur ekspresif yang merupakan ungkapan kekecewaan yang mencerminkan ajaran Budha untuk menghormati leluhur yang mana belum tergambar secara lancar dalam peragaan pernikahan kedua mempelai.

Ciri khas dari pernikahan etnis Tionghoa peranakan dari setiap tuturan adalah Pandita berhak menggunakan tindak tutur direktif, asertif, ekspresif, dan deklaratif sehingga tindak tutur komisif dari kedua mempelai bisa terlaksana. Dalam penelitian tindak tutur dalam presentasi MLM oleh Yustiana (2016), tindak tutur yang terklasifikasi terbatas pada tindak direktif, komisif dan asertif.

\section{DAFTAR PUSTAKA}

Austin, J.L. (1955). How to Do Things with Words. New York: Oxford University Press

Djajasudarma, F. (2006). Metode Linguistik Ancangan Metode Penelitian dan Kajian. Bandung: Refika Aditama.

Kurniasih, E. (2013). Peragaan Simbol dalam Upacara Ngeuyeuk Seureuh. Semarang: Universitas Diponegoro.

Searle, J.R. (1979). Expression and Meaning: Studies in the Theory of Speech Acts. Cambridge: Cambridge University Press.

Spradley, J.P. (1997). Metode Etnografi. Yogyakarta: PT Tiara Wacana.

Vandervaken, D. (1990). Meaning and Speech Acts. Cambridge: Cambridge University Press.

Yule, G. (1996). Pragmatics. Oxford: Oxford University Press.

Yustiana, Pramawati. (2016). Komponen Tutur dalam Presentasi Bisnis MLM Tianshi. Semarang: Universitas Diponegoro. 